\title{
The Role of Transformational Leadership and Organizational Climate in Organizational Self-Esteem of Mashhad Firefighters
}

\author{
$\underline{\text { Ahmad Arabshahi Karizi }}{ }^{1} \mathbb{D}$, Mohsen Mousavi $^{2} \mathbb{D}$
}

Date of submission: 10 Aug. $2021 \quad$ Date of acceptance: 19 Aug. 2021

\begin{abstract}
INTRODUCTION: This study aimed to investigate the impact of transformational leadership and organizational climate on the organizational self-esteem of the Mashhad Fire Department.

METHODS: The present applied research is a descriptive survey. The statistical population of this study consists of all 210 firefighters in Mashhad fire headquarters. The sample size was calculated according to Morgan's table comprising 132 individuals selected through simple random sampling. Data collection was accomplished through three questionnaires: Bass and Avolio's (2000) Transformational Leadership Questionnaire (TLQ), Sussman and Deep's (1989) Organizational Climate Questionnaire, and Pierce et al.'s (1989) Organizational-Based SelfEsteem Questionnaire, whose validity and reliability were confirmed. The collected statistical data were analyzed within SPSS and Smart PLS software.

FINDINGS: Data analysis confirmed all research hypotheses. Transformational leadership has a direct impact on organizational self-esteem with a path coefficient of 0.62. The organizational climate has a direct impact on organizational self-esteem with a path coefficient of 0.63 . Components of transformational leadership including idealized influence, inspirational motivation, intellectual stimulation, and individual consideration affect organizational selfesteem. Components of organizational climate including clarity of and agreement on organizational goals, clarity of and agreement on role, satisfaction with rewards, satisfaction with and agreement on procedures, and effectiveness of relations affect organizational selfesteem.
\end{abstract}

Original Article

CONCLUSION: Managing directors ought to reinforce employees' self-esteem to improve the performance of employees and boost productivity in the organization. In this regard, they must exercise an appropriate style in dealing with employees, which is the transformational leadership style. Moreover, a decent organizational climate should be created to build and boost self-esteem in employees and consequently enrich their performance towards fulfilling organizational goals.

Keywords: Organizational Climate; Organizational Self-esteem; Transformational Leadership.

How to cite this article: Arabshahi Karizi A, Mousavi M. The Role of Transformational Leadership and Organizational Climate in Organizational Self-Esteem of Mashhad Firefighters. Sci J Rescue Relief 2021; 13(3): 193-201.

\section{Introduction}

$\mathrm{T}$ he research studies conducted in recent years demonstrate the significance of transformational leadership as a flourishing management method in modern organizations. Moreover, studies point to organizational climate as a crucial factor in the efficacy and productivity of organizations. In the present study, we intend to examine whether transformational leadership and organizational climate can be beneficial in improving organizational status through enhancing organizational self-esteem. The answer to this question is doubly critical for the present study's statistical population, i.e., firefighters whose self-esteem considerably influences their

1- Assistant Professor, Department of Public Administration, Payame Noor University, Tehran, Iran

2- Master of Human Resource Management (HRM), Payame Noor University, Tehran, Iran

Correspondence to: Ahmad Arabshahi Karizi, Email: ahmad.arabshahi@gmail.com 
performance.

Self-esteem has been a concept of interest to numerous psychologists and investigators in the preceding few decades. It is undoubtedly among the more important personal, social, and psychological issues. In terms of antiquity, the topic of self-esteem is rooted in issues raised by scholars and philosophers of education in the past (1). Throughout the thousands of years of historical reports, the theories of philosophers and scholars have declared that for man, no proposition is more valuable than his judgment of himself (2). Self-esteem is the value we associate with ourselves and is our fundamental assessment of our value as human beings (3). Self-esteem is defined as the degree to which individuals consider themselves empowered, important, successful, and valuable (4). Organizational selfesteem reflects the value of intra-organizational "self-perception" that individuals display as members of the organization. Employees with high organizational self-esteem believe that they have a considerable and beneficial ability as a member of the organization (5). Self-esteem is a self-assessment that reflects a person's level of confidence in his or her abilities, importance, success, and value. Self-esteem is the general evaluation of one's value, and assessment of one's awareness of their ability, importance, and dignity in past experiences (2).

The basic concept of transformational leadership was introduced by Burns regarding his research on political leaders. Transformational leaders assist their followers to contemplate old issues from a fresh perspective and motivate them to strive beyond the ordinary. Transformational leaders instill in their followers to think beyond personal and individual goals and interests and to rather concentrate on bigger organizational, national, or global goals (6). The issue of transformational leadership was first raised by Downtown. In any case, its emergence as a substantial attitude to leadership began with the work by political sociologist James McGregor Burns titled "Leadership". In his work, Burns attempts to associate leadership as a role with compliance. He writes of leaders who were able to incite the motivations of followers resulting in successfully fulfilling the goals of followers and leaders (7). Bass and Avolio (1991) revealed that transformational leaders can enhance performance by encouraging and inspiring their followers and set higher expectations from their followers by establishing a sense of inspiration (8). Transformational leadership is a type of leadership in which leaders have divine gifts and provide spiritual motivation and particular attention to their followers and guide them by infiltrating their hearts (9). According to research studies, there are four components of transformational leadership: idealized influence, inspirational motivation, individual consideration, and intellectual stimulation (10).

The organizational climate can be defined as employees' perception of organizational events, actions, and behaviors. The process of understanding organizational climate illustrates how people detect unidentified intraorganizational issues and challenges independently and build a new framework of tools and objectives to use them (11). Climate distinguishes organizations from one another and accordingly influences the outcomes and activities of an organization. It can boost employee morale and motivation and influence the attitudes and actions of members. Organizational climate acts as a bridge. On one side of the bridge are the objective and tangible aspects of the organization, e.g., the structure, rules, and methods of leadership. On the other side are the morale and attitude of employees (12). Organizational climate is composed of the descriptive and discerning characteristics of an organization, e.g. structure and processes, interpersonal relationships, service compensation, employee behavior, performance expectation, and growth opportunities, which is stable over time, perceived by the members, and influential in their emotions and behavior (13).

Organizational climate is the general perception of employees about their work environment, which is influenced by many factors, e.g., formal and informal organization, employee personality, and the leadership method in the organization (14). For individual members within the organization, the climate is a set of traits and expectations that depict the overall pattern of organizational activities (15). The organizational climate is a stable quality experienced by employees, which influences their behavior and can be recognized as a part of the organizational environment (16). The organizational climate is the quality of the internal environment of the organization and is portrayed with certain characteristics such as openness, 
liveliness, calmness, informality, apathy, impersonality, hostility, hardness, and closeness (17). The organizational climate has a tangible impact on employee motivation. A satisfactory work environment increases employee morale, loyalty, and productivity (18). The organizational climate prompts employees to act innovatively. Rewarding and encouraging employees to innovate is vital to sustaining the innovation climate (19). Various factors influence the organizational climate: cultural, individual, social, material, physical, and organizational environments, ethical considerations, support, identity, and freedom (12).

Several research studies have been conducted on the present problem, some of which are referred to as research backgrounds. The results of the study by Shabani and Sohrabian Moghaddam (2019) showed that there is a positive and significant relationship between organizational climate and self-esteem. In the present study, we found that there is a direct and significant correlation between all five components of organizational climate including purpose, role, procedure, relationship, and reward with selfesteem (20). The study by Salarzehi et al. (2019) suggested that spiritual leadership has a positive and strong impact on organizational self-esteem (1). The study by Haji Sadeghi (2019) ascertained that organizational climate has a positive relationship with organizational self-esteem and job satisfaction (21). The study by Rahimi and Fesenduz (2015) revealed that spiritual leadership has a positive and statistically significant impact on workplace spirituality, organizational justice, and organizational self-esteem (22). In the study by Amiri (2013), the results obtained from the analysis exhibited that there is a positive and significant relationship between organizational self-esteem with organizational feedback and job adaptation and its dimensions (23). Gilani et al. (2015) conducted a study called "The Relationship between Workplace Spirituality and Organizational Self-Esteem". It confirmed the relationship between the three dimensions of spirituality in the workplace and organizational self-esteem (24). The study by Memarbashi et al. (2012) indicates that as the sense of unity and self-esteem increases, the rate of job performance increases as well (25). Lateral findings of the study by Nikpeyma et al. (2010) indicate that organizational climate can inflict self-esteem in employees (26). Fooladvand (2007) revealed that there is a statistically significant relationship between organizational climate and employees' mental health (27). A research study by Sholikhah et al. (2019) reflected that spiritual leadership has a positive and significant impact on organizational citizenship behavior (OCB). Moreover, spiritual leadership has a positive impact on organizational self-esteem (28). A study by Hunsaker (2017) suggested that spiritual leadership has a positive and significant impact on organizational citizenship behavior (29). A study by Arnetz et al. (2016) displayed no relationship between the dimensions of organizational climate and selfesteem (30). The results of the study by Haider et al. (2019) show that organizational self-esteem has a positive and significant impact on organizational citizenship behavior (31). Kark et al. (2003) reflected that transformational leadership styles can influence organizational innovation both directly and indirectly (32). In the present study, independent variables are transformational leadership and organizational climate, while the dependent variable is organizational self-esteem.

\section{Materials and Methods}

The present applied research is a descriptive survey. The statistical population of this study consists of all 210 firefighters in Mashhad fire headquarters. The sample size was calculated according to Morgan's table comprising 132 individuals selected through simple random sampling. Data collection was accomplished through three questionnaires: Bass and Avolio's (2000) Transformational Leadership Questionnaire (TLQ) (33), Sussman and Deep's (1989) Organizational Climate Questionnaire (34), and Pierce et al.'s (1989) OrganizationalBased Self-Esteem Questionnaire (35). The experts' statements confirmed the content vclimatealidity of the questionnaires. Nonetheless, in addition to confirming the reliability of the questionnaires based on background research studies, Cronbach's alpha was calculated to evaluate the reliability of the questionnaires, the results of which are presented in the Table 1.

Given that for all variables Cronbach's alpha values of above 0.7 , the tool is adequately reliable. Two methods of descriptive and inferential statistics were used to analyze the research data. Descriptive statistics are used to 
purify the collected data and to summarize the statistical sample and research variables. In the descriptive statistics, demographic variables (age, gender, etc.) are explored and measures of central tendency, dispersion, and frequencies (mean, variance, and frequency charts, etc.) are calculated. Meanwhile, inferential statistics, relying on structural equations, analyze the data and test the hypotheses using Smart PLS software. In general, there are two types of measurement and structural models. The measurement

Table 1. Cronbach's alpha for the Transformational Leadership Questionnaire (TLQ)

\begin{tabular}{|c|c|c|c|}
\hline Variable or Component & Questions & Number of Qs & Cronbach's Alpha \\
\hline Transformational Leadership & $1-20$ & 20 & $0 / 90$ \\
\hline Intellectual Stimulation & $1-5$ & 5 & $0 / 74$ \\
\hline Idealized Influence & $6-12$ & 7 & $0 / 80$ \\
\hline Inspirational Motivation & $13-16$ & 4 & $0 / 73$ \\
\hline Individual Consideration & $17-20$ & 4 & $0 / 72$ \\
\hline Organizational Climate & $1-20$ & 20 & $0 / 90$ \\
\hline Clarity of and Agreement on Organizational Goals & $1-4$ & 4 & $0 / 74$ \\
\hline Clarity of and Agreement on Role & $5-8$ & 4 & $0 / 70$ \\
\hline Satisfaction with Rewards & $9-12$ & 4 & $0 / 76$ \\
\hline Satisfaction with and Agreement on Procedures & $13-16$ & 4 & $0 / 71$ \\
\hline Effectiveness of Relations & $17-20$ & 4 & $0 / 77$ \\
\hline Organizational Self-Esteem & 10 & $0 / 7$ & $0 / 81$ \\
\hline
\end{tabular}

Table 2. Demographic Description

\begin{tabular}{c|c|ccccc}
\hline Age & Frequency & Percentage & Work Experience & Frequency & Percentage \\
\hline 20-25 years & 9 & $6 / 8$ & $<5$ & 48 & $36 / 4$ \\
26-30 years & 15 & $11 / 4$ & $6-10$ years & 50 & $37 / 9$ \\
31-35 years & 49 & $37 / 1$ & $11-15$ years & 24 & $18 / 2$ \\
35 & 59 & $44 / 7$ & $15<$ & 10 & $7 / 6$ \\
Total & 132 & 100 & Total & 132 & 100 \\
\hline
\end{tabular}

model specifies how to measure a latent variable using two or more observable variables. In other words, it relates a set of observable variables to a smaller set of latent variables. The structural model shows the relationships between internal and external latent variables and provides the possibility to assess the direction and intensity of causal effects between these variables. Therefore, measurement models define which observable variables measure which latent variables. Moreover, structural models determine which independent variables affect which dependent variable. The coefficients in these diagrams are divided into two categories. The first category is the relationships between latent variables and observable variables, which are called factor loads. Based on factor loads, it can be determined which variable contributes more to the measurement of the relevant structure and which variable contributes less. In other words, a variable with a larger factor load has a greater share in the measurement of the relevant structure. Likewise, a variable with a smaller factor load has a smaller share. All coefficients are tested using t-statistic. This statistic is significant when its absolute value is more than 1.96. Considering the level of significance, the hypotheses are either rejected or accepted.

\section{Findings}

Based on the data analysis, first descriptive statistics tables including demographic description and descriptive study of research variables, and then cases related to inferential statistics and tests of research hypotheses are presented.

According to the Table 2, it can be seen that $6.8 \%$ of the participants were $25-25$ years old, $11.4 \%$ were $26-30$ years old, $37.1 \%$ were $31-35$ years old, and $44.7 \%$ were $35 \leq$ years old. In addition, $36.6 \%$ of the participants had a service history of 5 years and less, $37.9 \%$ had a service history of 6 to 10 years, $18.2 \%$ had a service history of 11 to 15 years, and $7.6 \%$ had a service history of 15 years and more.

The Table 3 provides a descriptive study of research variables according to the opinions of 132 respondents selected from firefighters in Mashhad. It suggests that the mean score of 
opinions on organizational self-esteem is 3.86 and the dispersion equals 0.57 . The mean score of opinions regarding organizational climate is equal to 2.74 and the dispersion is 0.48 . The mean score of opinions on transformational leadership is 3.88 and the dispersion is equal to 0.47 . The following evaluates the normality of the variables based on the statistical data obtained about the research variables.

According to the Table 4, since the skewness and kurtosis for all variables are in the range $(-2,2)$, we conclude that the data is normally distributed. Hence, the Pearson correlation coefficient between all research variables is presented in the Table 5.

Table 3. Descriptive study of research variables

\begin{tabular}{|c|c|c|c|c|c|}
\hline Variable & Number & Minimum & Maximum & Mean & $\begin{array}{l}\text { Standard } \\
\text { Deviation }\end{array}$ \\
\hline Organizational Self-Esteem & 132 & 2 & 5 & $3 / 86$ & $0 / 57$ \\
\hline Organizational Climate & 132 & $1 / 35$ & $r / \Lambda$. & $2 / 74$ & $0 / 48$ \\
\hline Clarity of and Agreement on Organizational Goals & 132 & $\cdot 10$ & r/vo & $2 / 47$ & $0 / 57$ \\
\hline Clarity of and Agreement on Role & 132 & $1 / 50$ & $\varepsilon / \cdots$ & $2 / 82$ & $0 / 60$ \\
\hline Satisfaction with Rewards & 132 & $1 / 50$ & $\varepsilon / \cdots$ & $2 / 80$ & $0 / 53$ \\
\hline Satisfaction with and Agreement on Procedures & 132 & $1 / 00$ & $3 / 75$ & $2 / 76$ & $0 / 59$ \\
\hline Effectiveness of Relations & 132 & $1 / 50$ & $3 / 75$ & $2 / 86$ & $0 / 53$ \\
\hline Transformational Leadership & 132 & $2 / 41$ & $4 / 95$ & $3 / 88$ & $0 / 47$ \\
\hline Intellectual Stimulation & 132 & $2 / 60$ & $4 / 80$ & $3 / 81$ & $0 / 51$ \\
\hline Idealized Influence & 132 & $2 / 29$ & 5 & $3 / 82$ & $0 / 52$ \\
\hline Inspirational Motivation & 132 & $2 / 50$ & 5 & $4 / 02$ & $0 / 56$ \\
\hline Individual Consideration & 132 & $2 / 25$ & 5 & $3 / 86$ & $0 / 61$ \\
\hline
\end{tabular}

Table 4. Normality Test of the Variables

\begin{tabular}{ccc|}
\hline Variable & Skewness & Kurtosis \\
Intellectual Stimulation & $-0 / 05$ & $-0 / 38$ \\
Idealized Influence & $-0 / 18$ & $-0 / 36$ \\
Inspirational Motivation & $-0 / 21$ & $-0 / 59$ \\
Individual Consideration & $-0 / 75$ & $-0 / 05$ \\
Transformational Leadership & $-0 / 43$ & $0 / 24$ \\
Clarity of and Agreement on Organizational Goals & $-0 / 40$ & $0 / 95$ \\
Clarity of and Agreement on Role & $0 / 33$ & $-0 / 35$ \\
Satisfaction with Rewards & $-0 / 13$ & $0 / 20$ \\
Satisfaction with and Agreement on Procedures & $-0 / 76$ & $0 / 34$ \\
Effectiveness of Relations & $-0 / 44$ & $0 / 08$ \\
Organizational Climate & $-0 / 27$ & $0 / 30$ \\
Organizational Self-Esteem & $-0 / 51$ & $0 / 48$ \\
\hline
\end{tabular}

Table 5. Correlation between transformational leadership and organizational climate and their components with organizational self-esteem

\begin{tabular}{|c|c|c|c|}
\hline \multirow{2}{*}{ Variables } & \multicolumn{3}{|c|}{ Organizational Self-Esteem } \\
\hline & Number & Correlation Coefficient & Significance Level \\
\hline Intellectual Stimulation & 132 & $0 / 59 * *$ & $0 / 001$ \\
\hline Idealized Influence & 132 & $0 / 46 * *$ & $0 / 001$ \\
\hline Inspirational Motivation & 132 & $0 / 53 * *$ & $0 / 001$ \\
\hline Individual Consideration & 132 & $0 / 53 * *$ & $0 / 001$ \\
\hline Transformational Leadership & 132 & $0 / 61 * *$ & $0 / 001$ \\
\hline Clarity of and Agreement on Organizational Goals & 132 & $0 / 51 * *$ & $0 / 001$ \\
\hline Clarity of and Agreement on Role & 132 & $0 / 53 * *$ & $0 / 001$ \\
\hline Satisfaction with Rewards & 132 & $0 / 55^{* *}$ & $0 / 001$ \\
\hline Satisfaction with and Agreement on Procedures & 132 & $0 / 52 * *$ & $0 / 001$ \\
\hline Effectiveness of Relations & 132 & $0 / 55^{* *}$ & $0 / 001$ \\
\hline Organizational Climate & 132 & $0 / 62 * *$ & $0 / 001$ \\
\hline
\end{tabular}


The coefficients in this Table show that there is a relationship between transformational leadership and its components and organizational climate and its components with the organizational self-esteem of employees.

To test the hypotheses, we utilized structural equation modeling, path analysis, and Smart PLS software, the results of which are presented here:

\section{The first main hypothesis}

transformational leadership has a direct and significant impact on the organizational selfesteem of firefighters in Mashhad. The Figure 1 shows the path coefficients between the target variables which are reported and interpreted in the Table 6.

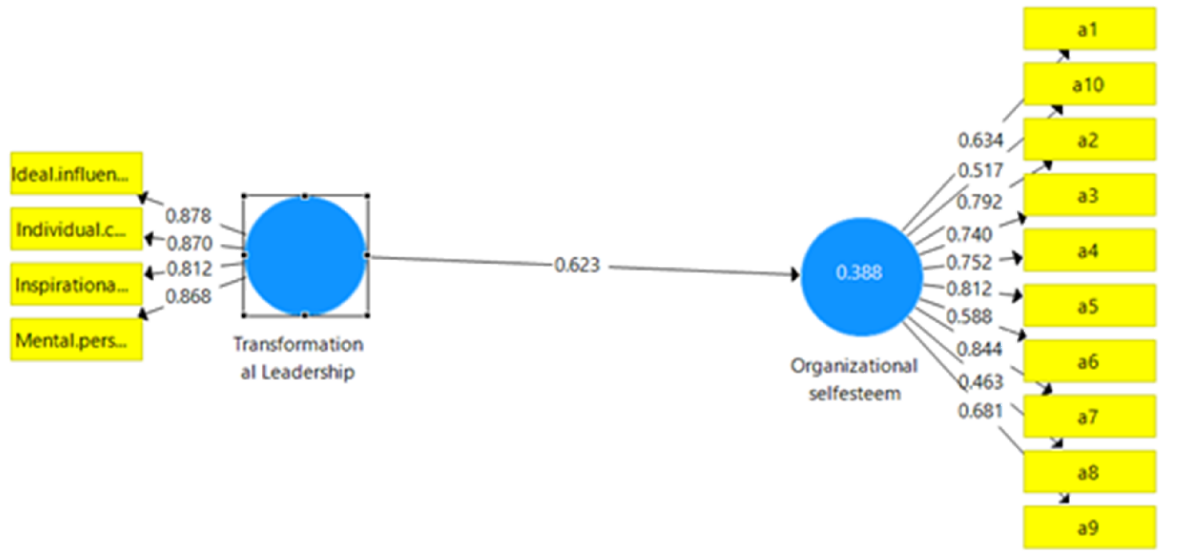

Figure 1. Path coefficient of transformational leadership on organizational self-esteem

Table 6. The direct impact of transformational leadership on organizational self-esteem

\begin{tabular}{ccc|c|c|c}
\hline Path & Path Correlation & Standard Error & t-statistic & Significance Level & Result \\
\hline $\begin{array}{c}\text { Transformational } \\
\text { Leadership } \rightarrow\end{array}$ & $0 / 62$ & $0 / 06$ & $9 / 51$ & $0 / 001$ & Confirmed \\
$\begin{array}{c}\text { Organizational Self- } \\
\text { Esteem }\end{array}$ & & & & \\
\hline
\end{tabular}

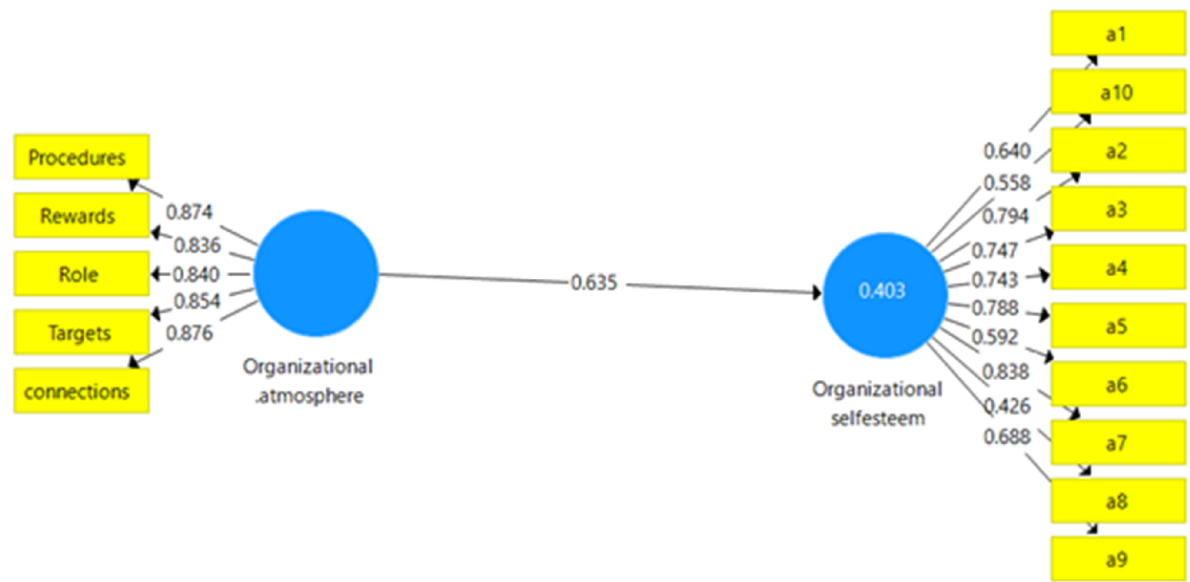

Figure 2. Path coefficient of organizational climate on organizational self-esteem

Table 7. The direct impact of organizational climate on organizational self-esteem

\begin{tabular}{cccccc}
\hline Path & Path Correlation & Standard Error & t-statistic & Significance Level & Result \\
$\begin{array}{c}\text { Organizational Climate } \\
\rightarrow \text { Organizational Self- } \\
\text { Esteem }\end{array}$ & $0 / 63$ & $0 / 07$ & $9 / 80$ & $0 / 001$ & Confirmed \\
\hline
\end{tabular}


According to the results in the Table 6, transformational leadership has a direct impact on organizational self-esteem. Given that the significance level is $<0.01$ and the t-statistic is $>$ 1.96 , we conclude with $99 \%$ confidence that increased organizational self-esteem leads to increased transformational leadership.

\section{The second main hypothesis}

organizational climate has a direct and significant impact on the organizational self- esteem of firefighters in Mashhad. The Figure 2 shows the path coefficients between the target variables which are reported and interpreted in the Table 7.

According to the results in the Table 7 , the organizational climate has a direct impact on organizational self-esteem. Given that the significance level is $<0.01$ and the t-statistic is $>$ 1.96 , we conclude with $99 \%$ confidence that increased organizational self-esteem leads to

Table 8. The impact of transformational leadership components on organizational self-esteem

\begin{tabular}{|c|c|c|c|c|c|}
\hline Path & $\begin{array}{c}\text { Path } \\
\text { Correlation }\end{array}$ & Standard Error & t-statistic & Significance Level & Result \\
\hline $\begin{array}{l}\text { Intellectual Stimulation } \rightarrow \\
\text { Organizational Self-Esteem }\end{array}$ & $0 / 60$ & $0 / 06$ & 9/94 & $0 / 001$ & Confirmed \\
\hline $\begin{array}{l}\text { Idealized Influence } \rightarrow \\
\text { Organizational Self-Esteem }\end{array}$ & $0 / 48$ & $0 / 09$ & $5 / 37$ & $0 / 001$ & Confirmed \\
\hline $\begin{array}{l}\text { Inspirational Motivation } \rightarrow \\
\text { Organizational Self-Esteem }\end{array}$ & $0 / 55$ & $0 / 06$ & $8 / 65$ & $0 / 001$ & Confirmed \\
\hline $\begin{array}{l}\text { Individual Consideration } \rightarrow \\
\text { Organizational Self-Esteem }\end{array}$ & $0 / 57$ & $0 / 05$ & $10 / 61$ & $0 / 001$ & Confirmed \\
\hline
\end{tabular}

Table 9. The direct impact of clarity and agreement of organizational goals on organizational self-esteem

\begin{tabular}{|cccc|cc}
\hline Path & $\begin{array}{c}\text { Path } \\
\text { Correlation }\end{array}$ & $\begin{array}{c}\text { Standard } \\
\text { Error }\end{array}$ & $\begin{array}{c}\mathbf{t}- \\
\text { statistic }\end{array}$ & $\begin{array}{c}\text { Significance } \\
\text { Level }\end{array}$ & Result \\
\hline $\begin{array}{c}\text { Clarity of and Agreement on } \\
\text { Organizational Goals } \rightarrow\end{array}$ & $0 / 52$ & $0 / 08$ & $6 / 88$ & $0 / 001$ & Confirmed \\
$\begin{array}{c}\text { Organizational Self-Esteem } \\
\text { Clarity of and Agreement on Role } \rightarrow\end{array}$ & $0 / 57$ & $0 / 05$ & $9 / 98$ & $0 / 001$ & Confirmed \\
$\begin{array}{c}\text { Organizational Self-Esteem } \\
\text { Satisfaction with Rewards } \rightarrow\end{array}$ & $0 / 58$ & $0 / 06$ & $9 / 5$ & $0 / 001$ & Confirmed \\
$\begin{array}{c}\text { Organizational Self-Esteem } \\
\text { Satisfaction with and Agreement on }\end{array}$ & $0 / 55$ & $0 / 06$ & $9 / 13$ & $0 / 001$ & Confirmed \\
$\begin{array}{c}\text { Procedures } \rightarrow \text { Organizational Self-Esteem } \\
\text { Effectiveness of Relations } \rightarrow\end{array}$ & $0 / 60$ & $0 / 60$ & $10 / 98$ & $0 / 001$ & Confirmed \\
\hline Organizational Self-Esteem & & & & & \\
\hline
\end{tabular}

increased organizational climate.

In the following, sub-hypotheses are tested. Several sub-hypotheses have been associated with the impact of transformational leadership components on organizational self-esteem, which is presented in the Table 8 to avoid research rhetoric.

Several sub-hypotheses have been associated with the impact of organizational climate components on organizational self-esteem, which is presented in the Table 9 to avoid research rhetoric.

\section{Discussion and Conclusion}

The present study aimed to investigate the impact of transformational leadership and organizational climate on organizational selfesteem. In this regard, two main hypotheses and nine sub-hypotheses have been proposed. According to the data collected from the statistical population (Mashhad Fire Department), the hypotheses were analyzed and tested. The data analysis results confirmed all the hypotheses. Transformational leadership has a direct impact on organizational self-esteem with a path coefficient of 0.62. Organizational climate has a direct impact on 
organizational self-esteem with a path coefficient of 0.63. The components of transformational leadership comprise intellectual stimulation, idealized influence, inspirational motivation, and individual consideration which influence organizational self-esteem with path coefficients of $0.60,0.48,0.55$, and 0.57 , respectively. Components of organizational climate include clarity of and agreement on organizational goals, clarity of and agreement on role, satisfaction with rewards, satisfaction with and agreement on procedures, and effectiveness of relations which influence organizational self-esteem with path coefficients of $0.52,0.57,0.58,0.55$, and 0.60 , respectively. On the one hand, hypothesis testing shows that transformational leadership and its components (intellectual stimulation, idealized influence, inspirational motivation, and individual consideration) have a direct and significant impact on organizational self-esteem. The finding is consistent with the results of previous research studies, e.g., Salarzehi et al. (2019), Rahimi and Fesenduz (2015), Gilani et al. (2015), and Sholikhah et al. (2019). On the other hand, hypothesis testing indicates that the organizational climate and its components (clarity of and agreement on organizational goals, clarity of and agreement on role, satisfaction with rewards, satisfaction with and agreement on procedures, and effectiveness of relations) have a direct and significant impact on organizational self-esteem. The finding is inconsistent with the findings of Arnetz et al. (2016) and consistent with the findings of Shabani and Sohrabian Moghadam (2019), Nikpeyma et al. (2010), Fooladvand (2007), and Haji Sadeghi (2019). Given that transformational leadership has a positive and significant impact on organizational self-esteem, it is suggested that transformational leaders play their crucial part by setting organizational goals, clarifying what is expected of employees, depicting the vision of a desirable future, and encouraging the employees to achieve it. Leaders must build a sense of hope in employees and motivate them to maintain a positive attitude towards themselves and the organization and to consider themselves valuable for the organization. Followers with higher levels of selfesteem are delighted with their work and career and never accept failure at work. Furthermore, once the firefighters feel that they are taken care of, their needs are met, their efforts are appreciated, and that they have an essential and valuable place in society and the organization, their self-esteem will boost and they will dedicate themselves to the organization and accomplishing organizational goals. To build a favorable climate and environment for work, it is suggested that leaders provide conditions for employees to do their job successfully by updating their knowledge, participating in training workshops, and getting acquainted with other valid methods. It is suggested that firefighters establish a better climate in the organization by holding regular meetings and encouraging employees to participate, conveying problems and shortcomings in the workplace, and coming up with solutions to cope with them based on consultation, consensus, and execution. It is suggested that firefighters provide a healthier and friendlier atmosphere to improve the self-esteem of employees working in the organization, which is vital for additional efficiency and effectiveness of the organization.

\section{Acknowledgments}

We would like to sincerely thank all those who have assisted us in various stages of our research, especially the Mashhad Fire Department.

\section{References}

1. Salarzehi H, Keshteh KA, Ahang F, Ghaffari H. Investigating the Effect of Spiritual Leadership on Organizational Citizenship Behavior of University Faculty Members Considering the Mediating Role of Organizational Self-Esteem. Development of th logistic\& Human Resources Management 2019; 54: 50-75. [In Persian]

2. Mohajeran B, Ghaleei A, Ashrafi SF, Darvishi Z. A Study of the Relationship Between Social Capital and Organizational Health by the Mediating Role of Organizational Self-Esteem Journal of Applied Sociology 2018; 29: 9-12. [In Persian]

3. Mahdad A, Adibi Z, Saffari S. Predicting of Self Efficacy through Perceived Organizational Support and Self - Esteem (Case: Isfahan province Gas Company). Strategic Studies in Petroleum and Energy Industry 2018; 9: 59-82. [In Persian]

4. Hakimi I. Exploring the Effect of Leader-Member Exchange on Envy and Deviant Work Behaviors: The Moderating Role of Organizational Justice Perception, Self-Esteem and Neuroticism. Organizational Behavior Studies Quarterly 2020; 9: 29-56. [In Persian]

5. Hosseini A, Ghorbani PA, Akbari A. The Effect of Workplace Ostracism on Workplace Behaviors with the Mediating Role of Organization-Based Self-Esteem and the Moderating Role of Perceived Organizational Justice. Abolhassan. JOMC 2019; 17: 569-86.[In Persian]

6. Mirzakhani A, Ahmadi ME, Mohammadinia R, Amin SN. The Effect of Transformational Leadership on Realization of Community Policing Approach to with the Mediating role of Culture and Ethical Values in 
Workplace. Police Management Studies Quarterly 2020; 15 : 117-34.[In Persian]

7. Shojaei M, Bandehi SS. (2016, Dec 20). Transformational Leadership: Background, Components, and Related Concepts. The 2nd International Conference on Management \& Economics in the 21st Century. Tehran, Iran [In Persian]

8. Mansourkiaei M. The effect of managers' transformational leadership style on the exhaustion of high school teachers in Royan. JMEP 2020; 2: 93-111. [In Persian]

9. Ahmadi BS, Khazadean S. Investigating the relationship between transformational leadership and human resource agility in the Disciplinary Command of Mazandaran Province.Police Organizational Development 2020; 17: 3148. [In Persian]

10. Pourkarimi J, Homayeni DA, Fakoor R, Najafpour Y. An Investigation of the Mediating Effect of Organizational Creativity on the Relationship between Transformational Leadership and Organizational Innovation (Case Study: Employees of the Ministry of Science, Research and Technology).HRMJ 2021; 12: 153-82. [In Persian]

11. Tavakkoli A, Motamedi Galogahi F. The Impact of Social Capital on Strategic Innovation with an Emphasis on the Mediating Role of Innovative Organizational Climate.Social Capital Management 2020; 7: 87-109. [In Persian]

12. Ebrahimi GGA, Nour Rahmani M. Review on Related Models to Organizational Atmosphere. JMAR 2016; 3: 105-14. [In Persian]

13. Hakak M, Sepahvand R, Zare F, Mousavi S N. The role of organizational toxic climate on organizational inertia with regard to the mediator role of the organizational silence. Strategic Studies in Petroleum and Energy Industry 2019; 10:149-74. [In Persian]

14. Ahdi S, Heidarizadeh Z, Hassani M, Qasemzadeh A. The Role of Organizational Climate in the Relationship between Islamic Work Ethics and Deviant Behavior in the Workplace and the Quality of Services. Scientific Journal of Islamic Management 2020; 28: 171-93. [In Persian]

15. Chen C, Huang J. How organizational climate and structure affect knowledge management-The social interaction perspective. Int J Inf Manage 2007; 27: 10418.

16. Faisal QF, Jeffery H. Mediation of Psychological Capital between Organizational Climate and Organizational Citizenship Behavior. PJCSS 2014; 8: 453- 70.

17. Zamani PA, Karimi F. The relationship between organizational climate and organizational citizenship behaviors of the staff members in the Department of Education in Isfahan city. Int J Educ Psychol Res 2017; 3: 53-60. [In Persian]

18. Permarupan P Y, Saufi R A, Kasim R S R. The Impact of Organizational Climate on Employee's Work Passion and Organizational Commitment. Procedia - Social and Behavioral Sciences, 2013; 107: 88 - 95.

19. Balkar B. The Relationships between Organizational Climate, Innovative Behavior and Job Performance of Teachers. IOJES 2015; 7: 81-92.

20. Shabani A, Sohrabian MA. The Relationship between Organizational Climate and Self-esteem among Staff of Sports and Youth Departments of Tehran Province. JMTE 2019; 14: 111-19. [In Persian]
21. Haji Sadeghi B. Investigating the relationship between organizational climate and organizational self-esteem with job satisfaction of employees. 2019. Golpayegan Payam Nor-Profit Higher Education Institute. MSc dissertation. [In Persian]

22. Rahimi G, Hedayat Fesenduz A. Model the impact of spiritual leadership on spirituality at work; Mediators of organizational justice and organizational self-esteem. Journal of Modern Management Engineering 2015; 3\&4: 23-38. [In Persian]

23. Amiri N. Investigating the relationship between organizational self-esteem and organizational feedback and Job adjustment among employees of Zahedan university of medical sciences. 2013. University of Sistan and Baluchestan. MSc dissertation. [In Persian]

24. Hemmati NGM, Hasanzadeh M, Monzavi F. Investigating the Relationship between Workplace Spirituality and Organization-Based SelfEsteem. Organizational Behavior Studies Quarterly 2015; 4: 51-74.[in Persian]

25. Memarbashi AM, Sabri NR, Abdekhodaei M. The relationship between Sense of Cohesion (SOC) and selfesteem with job performance. Quarterly of Career and Organizational Counseling 2012; 4: 66-78. [In Persian]

26. Nikpeyma N, Gholamnejad H. Influencing Factors on Hospital Nurses' Perspectives about Different Dimensions of Organizational Climate. Journal of Hayat 2010; 16:86-86. [In Persian]

27. Fooladvand K. The relationship between organizational climate and the mental health of hospital workers in Ilam State Hospitals. SJIMU 2007; 15:44-50. [In Persian]

28. Sholikhah, Z, Wang $\mathrm{X}, \mathrm{Li} \mathrm{W}$. The role of spiritual leadership in fostering discretionary behaviors: The mediating effect of organization based self-esteem and workplace spirituality. IJLMA 2019; 61: 232-49.

29. Hunsaker WD. Spiritual Leadership And Organizational Citizenship Behavior: Exploring The Conditional Effects Of Self-Determination And Confucian Mindset. IJBS 2017; 18: 485-502.

30. Arnetz B, Lucas T, Arnetz J. Organizational Climate, occupational stress, and Employee Mental Health: Mediating Effect of organizational Efficiency. JOEM 2011; 53: 34-42.

31. Haider S, de Pablos Heredero C, Ahmed M. A threewave time-lagged study of mediation between positive feedback and organizational citizenship behavior: the role of organization-based self-esteem. Psychol Res Behav Manag 2019; 12:241-53.

32. Kark R, Shamir B, Chen G. The Two Faces of Transformational Leadership: Empowerment and Dependency Journal of Applied Psychology 2003; 88: 246-55.

33. Bass B M, Avolio B J. MLQ multifactor leadership questionnaire sampler set: Instrument (Leader and Rater Form) and Scoring Guide (Form 5X-Short), 2nd ed., Mind Garden, Palo Alto, CA. 1996.

34. Sussman L, Deep S. Comex: The communication experience in human relationas. $2^{\text {nd }}$ ed. South-Western Pub; 1989.

35. Pierce J L, Gardner D G, Cummings L L, Dunham R B. Organization-based self- esteem: construct definition, measurement and validation. AMJ 1989; 32: 622-48. 